\title{
PBX3 wt Allele
}

National Cancer Institute

\section{Source}

National Cancer Institute. PBX3 wt Allele. NCI Thesaurus. Code C51292.

Human PBX3 wild-type allele is located within 9q33-q34 and is approximately $220 \mathrm{~kb}$ in length. This allele, which encodes pre-B-cell leukemia transcription factor 3 protein, is involved in transcriptional activation regulation. 